\title{
The Effects of 6-Week Core Training on Selected Biomotor Abilities in Soccer Players
}

\author{
Bulent Turna ${ }^{1}$ \\ ${ }^{1}$ Akdeniz University, Faculty of Sport and Physical Education, Antalya, Turkey \\ Correspondence: Bulent Turna, Akdeniz University, Faculty for Sport and Physical Education, Antalya, Turkey. \\ E-mail: bulentturna@akdeniz.edu.tr
}

Received: October 21, 2019

Accepted: December 2, 2019 Online Published: January 6, 2020

doi:10.5539/jel.v9n1p99

URL: https://doi.org/10.5539/jel.v9n1p99

\begin{abstract}
This study aims to analyze the effects of 6-week core training on certain biomotor abilities for footballers in the pubertal period. Accordingly, 30 male footballers who attend football courses regularly participated in the study. Footballers were divided into two groups; 15 of them were assigned to the Core Training Group (CTG) (age: 9.73 years; height: $139 \mathrm{~cm}$; and body weight: $33.66 \mathrm{~kg}$.) while 15 of them were assigned to the Conventional Training Group (CONTG) (age: 10.06 years; height: $139 \mathrm{~cm}$; and body weight: $35.32 \mathrm{~kg}$ ). While CONTG was applying the traditional training protocol, CTG additionally applied core strength exercises (two days a week for 10-15 min.). The selected biomotor tests were applied to both groups before and after the 6-week application. Between pre- and post-test values in the CTG, a statistically significant difference was found in flamingo balance, core stabilization balance, hand grip strength, $30 \mathrm{sec}$. abdominal crunch and $30 \mathrm{~m}$ sprint tests $(\mathrm{p}<0.05)$. In the CONTG, a statistically significant difference was found in 30-second push-up test values between pre- and post-tests $(\mathrm{p}<0.05)$. Comparing the pre-tests between groups, a statistically significant difference was found in flamingo balance and vertical jump tests $(\mathrm{p}<0.05)$. Also, comparing the post-tests, a statistically significant difference was found in core stabilization balance and vertical jump tests $(\mathrm{p}<0.05)$.

As a result of this study, it was found that core training to be performed in addition to the traditional football training positively contributed to basic motor development.
\end{abstract}

Keywords: football, core strength, balance

\section{Introduction}

The human body is in physical, physiological, biomotoric and psycho-mental forms with a great balance (homeostasis) and adaptation (Aktaş et al., 2019; Çakmakçı et al., 2018). One of the most popular sports branches in Turkey and across the world, football requires high physical performance when it is played at a professional level. As it is a team and struggling sport involving control, it requires high-level sportive performance such as durability, strength, pace, and agility. Today, this requires footballers from all positions to have many motor abilities at a high level (Köklü, Özkan, Alemdaroğlu, \& Ersöz, 2009; Akyüz, Uzaldi, Akyüz, \& Doğru, 2016; Sevim, 2006; Tatlici \& Cakmakci, 2019). In addition, it involves various complex movements within the game such as walking, jogging, dribbling with sprint, shooting, and passing (Eniseler, 1994; Boyle 2004) and these days small times make teams or players winner (Tatlıc1 et al., 2018). Athletes with excellent technique and tactics can achieve success if they develop their basic motoric features systematically (Ünlü et al., 2018).

Strength is a biomotor ability determining effectiveness in sports branches. Strength is generally described as the ability to withstand resistance or the ability to endure against resistance at a certain level (Boyle, 2004). Strength and other biomotor abilities are mutually affected development processes. The level of need for strength is different for each sports branch. For children, strength exercises are generally performed by using their own body weight (Muratl, 2007). Increasing muscular strength provides a significant advantage to athletes in almost all sports branches. Developing groups of the most commonly used muscles in a certain sports branch is the further specialization of strength. Various training methods were developed as a result of scientific research on increasing muscular strength. One of these methods is the core training method (McGill, 2010).

In addition to these physiological features, the athlete has to perfect these features through exercises (Tatlic1 et 
al., 2018). Core training is among the most popular methods performed for strength training for footballers. Therefore, recently, core training has become an essential part of training programs (Riewald, 2003). As core muscles are located at the center of the body, they play an active role in most of the body movements (Sato \& Mokha, 2009). The core area involves fore body muscles, back body muscles, upper body diaphragm, and lower body pelvic floor muscle, and when this area is strong, it prevents the formation of posture disorders by protecting spine (Handzel, 2003; Schiffer, Schulte, \& Sperlich, 2008).

The core area involves abdomen, lower back, and hips. In addition, the core area is described as the area between the rib CTGe and kneels (Saeterbakken, Tillaar, \& Seiler, 2011). According to another description, lumbopelvic hip complex is regarded as the core (Bergmark, 1989; McGill, Grenier, Kavcic, \& Cholewicki, 2003; Akyüz, Agar, Akyüz, \& Dogru, 2016; Doğru, Akyüz, Akyüz, Murat, Çoban, \& Dilber, 2018; Akyüz, Çoban, Dilber, Ergün, Murat, Özkan, \& Akyüz, 2016). According to a newer approach, the core concept is described as a training specially designed for muscle activity and integrity of muscle groups forming the body, supporting and wrapping the spine, and playing an active role in upper extremity strength transitions (Parkhouse \& Ball, 2011; Stanton, Reaburn, \& Humphries, 2004). Core training is a training program enabling strength development of muscles in the lumbopelvic hip area involved in core stability through movements performed with body weight (Akman, Kabadayı, Elioz, Cilhoroz, \& Akyol, 2013; Clark, 2001). Core training is usually preferred for developing balance, strength, anatomic function and flexibility (Sun, Gao, Dou, \& Tang, 2016). Core training supports neural adaptation while leading to positive structural change in muscles. Furthermore, core training improves core stability and strength by developing proprioceptive senses and providing muscular improvement and body control (Iacono, Martone, Alfieri, Ayalon, \& Buono, 2014). Core strength and core stabilization have different meanings. Core stabilization is described as the stabilization of the spinal column through the activation of core muscles while core strength means the strength generated by the contraction of core muscles and the help of internal abdominal pressure (Faries \& Greenwood, 2007). A developed core area enables athletes to withstand training load further. It enables athletes to perform technical movements more efficiently. Thus, core area muscles constitute the strength dynamics of the body. Core muscles may not generate strength as high as certain muscles in other parts of the body do, however, during a sportive activity, they play an important role in transferring the power. Core training develops body control and balance. These applications enable the strength development of major and minor muscle groups. Therefore, core training reduces the possibility of injury (Imai, Kaneoka, Okubo, \& Shiraki, 2014).

Upper extremity muscles in the core area are an effective factor in struggling during a football play (Handzel, 2003; Schiffer, Schulte, \& Sperlich, 2008). The more the core area is developed, the more driving muscle strength of the upper extremity increases (Saeterbakken, Tillaar, \& Seiler, 2011; Afyon, 2014). For young footballers, in addition to basic training, the emphasis is placed on core strength training to balance extremity strength (Dello Iacono, Padulo, \& Ayalon, 2016). Abdominal crunch and push-up tests are used for muscle strength measurements of the abdominal area as it is the upper extremity and core area for athletes (Biçer, Savucu, Kutlu, Kaldırıme1, \& Pala, 2004).

As a result of the literature review, it can be said that core training has various effects on certain biomotor abilities. Therefore, adding core training to footballers' annual training program positively affects performance. The aim of this study was to analyze the effect of a 6-week core training on selected biomotor abilities for male footballers in the pubertal period.

\section{Material and Method}

\subsection{Participants}

Thirty athletes who regularly play football at Burdur Fenerbahçe Futbol Okulu and Isparta Altınordu Futbol Okulu participated in this study. The athletes were divided into two groups; 15 of them were assigned to the Conventional Training Group (CONTG) while the other 15 were assigned to the Core Training Group (CTG). Physical characteristics of the athletes are given in Tables 1 and 2. 
Table 1. Physical characteristics of the athletes in conventional training group and core training group

\begin{tabular}{|c|c|c|c|c|c|}
\hline & $\mathrm{N}$ & Minimum & Maximum & Mean & SD \\
\hline \multicolumn{6}{|l|}{ CTG } \\
\hline Age (year) & 15 & 9.00 & 11.00 & 9.73 & .59 \\
\hline Sports Age (year) & & 1.00 & 1.00 & 1.00 & .00 \\
\hline Height $(\mathrm{cm})$ & & 129.00 & 147.00 & 139.00 & 6.17 \\
\hline Body Weight (kg) & & 26.00 & 46.00 & 33.66 & 5.83 \\
\hline Body Mass Index $\left(\mathrm{kg} / \mathrm{m}^{2}\right)$ & & 14.50 & 23.80 & 17.34 & 2.77 \\
\hline \multicolumn{6}{|l|}{ CONTG } \\
\hline Age (year) & 15 & 9.00 & 11.00 & 10.06 & .79 \\
\hline Sports Age (year) & & 1.00 & 1.00 & 1.00 & .00 \\
\hline Height $(\mathrm{cm})$ & & 128.00 & 148.00 & 139.40 & 5.88 \\
\hline Body Weight (kg) & & 26.50 & 48.00 & 35.32 & 5.80 \\
\hline Body Mass Index $\left(\mathrm{kg} / \mathrm{m}^{2}\right)$ & & 15.30 & 24.80 & 18.24 & 2.84 \\
\hline
\end{tabular}

\subsection{Procedure}

Training programs were divided into two as CTG and CONTG. The total duration of the training applied to both groups were equal.

Core Training group: In addition to the Conventional Training Group program (Table 3), the core strength movements in Table 2 were applied to CTG for approximately 15 minutes per session on an artificial turf football field twice a week for 6 weeks.

Traditional Training Group: The training program shown in Table 3 was applied to CONTG for 60-75 minutes on an artificial turf football field twice a week for 6 weeks.

Core Training Program: In this training program, 10 movements particular to the core area was adopted (One Side Plank, Elbow Plank, V Crunch, Leg Drops/Leg Raise, Mountain Climbers, Scissor Kicks, Squat, Alternate Superman, Glute Bridge, Hip Extension). Before the training, general and special warm-ups appropriate for the movements were performed for 15-20 min. The movements were applied with pyramidal method and intervals appropriate for loads were given. In the core training program, for certain movements, the ever-increasing loads principle is adopted as well as linear increasing in duration and repetition number.

Table 2. 6-week core training program

\begin{tabular}{|c|c|c|c|}
\hline Movements & 1-2 Weeks Duration/Repetition & 3-4 Weeks Duration/Repetition & 5-6 Weeks Duration/Repetition \\
\hline One Side Plank & 25 sec. $* 2$ Rep. & 30 sec. $* 2$ Rep. & 35 sec. *3 Rep. \\
\hline Elbow Plank & 25 sec. *2 Rep. & 30 sec. *2 Rep. & 35 sec. *3 Rep. \\
\hline V Crunch & 25 sec. *2 Rep. & 30 sec. *2 Rep. & 35 sec. *3 Rep. \\
\hline Leg Drops/Leg Raise & 25 sec. $* 2$ Rep. & 30 sec. *2 Rep. & 35 sec. $* 3$ Rep. \\
\hline Mountain Climbers & 15 sec. *2 Rep. & 20 sec. *2 Rep. & 25 sec. *3 Rep. \\
\hline Scissor Kicks & 25 sec. *2 Rep. & 30 sec. *2 Rep. & 35 sec. *3 Rep. \\
\hline Squat & $20 * 2$ Rep. & $25 * 2$ Rep. & 30*3 Rep. \\
\hline Alternate Superman & 25 sec. *2 Rep. & 30 sec. *2 Rep. & 35 sec. *3 Rep. \\
\hline Glute Bridge & 25 sec. $* 2$ Rep. & 30 sec. *2 Rep. & 35 sec. *3 Rep. \\
\hline Hip extension & 25 sec. *2 Rep. & 30 sec. *2 Rep. & 35 sec. *3 Rep. \\
\hline
\end{tabular}


Table 3. 6-Week traditional football training program

\begin{tabular}{ll}
\hline Weeks & Drills \\
\hline 1st Week & Warmup+Drill1+Small-sided Game+Stretching \\
Saturday & Warmup+Drill2+Small-sided Game+Stretching \\
Sunday & \\
2nd Week & Warmup+Drill3+Small-sided Game+Stretching \\
Saturday & Warmup+Drill4+Small-sided Game+Stretching \\
Sunday & \\
3rd Week & Warmup+Drill5+Small-sided Game+Stretching \\
Saturday & Warmup+Drill6+Small-sided Game+Stretching \\
Sunday & \\
4th Week & Warmup+Drill1+Small-sided Game+Stretching \\
Saturday & Warmup+Drill2+Small-sided Game+Stretching \\
Sunday & \\
5th Week & Warmup+Drill3+Small-sided Game+Stretching \\
Saturday & Warmup+Drill4+Small-sided Game+Stretching \\
Sunday & \\
6th Week & Warmup+Drill5+Small-sided Game+Stretching \\
Saturday & Warmup+Drill6+Small-sided Game+Stretching \\
Sunday &
\end{tabular}

Drill 1: Footballers are divided into four groups, facing each other in pairs. One of the pairs goes forward and the other pair goes across, they make a controlled pass at first and then they continue to make a one-touch pass.

Drill 2: When the football coach gives a color instruction, the footballer standing on the balls of his feet within the center circle touches the cones and comes back to the center circle and returns his standby position on the balls of his feet until the next color instruction. After 3-5 instructions, the footballer controls the pass he receives from another footballer getting in line with the ball next to the goal post and makes an instep drive and gets back in the line. The footballers passing the ball goes to the center circle.

Drill 3: The footballers getting in line against the cones run without the ball until the cones as the football coach gives instruction and make a turn from the cone, then control the pass he receives from the footballer behind him and get back in the line. In another drill, with the pass he receives from the footballer behind him, he gets back in the line on his right side.

Drill 4: After divided into two equal groups, between two cones, the footballer from the first group leaves the pass he receives from the second group with a one-touch pass to the footballer behind him from the first group and makes his turn. Then, he shoots the ball in front of him to the goal post.

Drill 5: The footballers dribble randomly in the area within four cones, as the football coach gives an instruction, they dribble until the lines on the right and left side and come back to the area where they start. The group is divided into two teams and they continue dribbling. The team that comes back to the area the latest after the football coach gives an instruction are asked to perform a pre-defined punishment.

Drill 6: As the football coach gives an instruction, the footballers at the stairs start to climb up. When they finish climbing up, they get ahead of the cone and make a turn with the pass from the next footballer and shoot the ball to the goal post.

\subsection{Data Collection Tools and Procedure}

\subsubsection{Vertical Jump Test}

Takei jump meter was attached to the abdominal area of the athlete. With arms free and two feet within a determined area, the footballer was asked to jump vertically and land within a determined area. The third round was performed and the highest value in $\mathrm{cm}$ was recorded.

\subsubsection{Push-Up and Abdominal Crunch Test}

The athletes were asked to lie flat with hands at sides, body stretched, feet adjacent, and supported by an assistant at their feet. The athletes were asked to curl up their body and then repeat the movement.

Athletes' repetition numbers were recorded. Measurement of push-up movement was performed in the push-up position. Arms are bent at elbows, the body is lowered and pushed up, and the number of repetitions achieved within $30 \mathrm{sec}$. was recorded (Biçer, Savucu, Kutlu, Kaldırımcı, \& Pala, 2004). 


\subsubsection{The 30-Meter Sprint Test}

Before the run, the athletes were asked to take the running position. When they felt ready, they started to run and kept running at maximal speed for $30 \mathrm{~m}$. The data obtained were recorded in seconds and split seconds.

\subsubsection{Core Stabilization Performance Test}

The protocol developed by Mackenzie (2005) was used for the measurement. Validity and reliability (95\%, 0.94-0.99) analysis of the test (Sport-Specific Core Muscle Strength \& Stability Plank Test) were made by Tong et al. (2013). This test is used for observing the core strength and stability development of athletes. The test requires a flat floor, mat, stopwatch and an assistant. Duty of the assistant is to warn the athlete for the next movement. During the test, back and neck position should be flat and parallel to the floor. If the athlete breaks this position, the test is stopped (Mackenzie, 2005). Duration of the test is $180 \mathrm{sec}$.

\subsubsection{Back Strength Test}

The athletes placed their feet on Takei dynamometer bench with knees and arms stretched, back flat and body slightly bent further. They were asked to pull the dynamometer bar they grip with their hands by using their back muscles vertically at a maximum level (Boyle, 2004).

\subsubsection{Leg Strength Test}

After the athletes placed their feet on Takei dynamometer bench with arms stretched, back flat, legs bended at knee, and body slightly bended further, they were asked to pull up the dynamometer bar they grip with their hands by only using their legs and not their back until the knees reach the extension (Muratl, 2007).

\subsubsection{Flamingo Balance Test}

Footballers were asked to step up onto a balance board $(50 \mathrm{~cm}$. length, $4 \mathrm{~cm}$. height, $3 \mathrm{~cm}$. width) and stand in balance for $1 \mathrm{~min}$. When the balance was broken (drops foot, falls foot from the bench, contacts floor with any part of the body, etc.), the time was stopped. The time was resumed when the athlete got back his balance by stepping up onto the balance bench. The test continued as such for one minute. When the time was up, each balancing attempt (after falling) by the research group was counted and this number was recorded as score when the one-minute time was up after the test was completed (Hazar \& Taşmektepligil, 2008).

\subsubsection{Long Jump with Pause Test}

At the back of the start line, with toes out front the line, arms free, the athletes were asked to jump to the farthest point they can, and the measurement was made from the point the sole of their feet touched the ground. Each athlete performed the test twice and the best performance achieved was recorded in sec. (Baechle \& Earle, 2008).

\subsubsection{Right- and Left-Hand Grip Strength Test}

In the study, Takei hand dynamometer grip was used for the measurement. The measurement was recorded with the athlete standing in anatomical position. The athlete took the dynamometer in the hand he preferred. Later, the same procedure was repeated for the other hand. The procedure was repeated three times and the best value was recorded in $\mathrm{kg}$ (Muratl1, 2007).

\subsection{Data Analysis}

Descriptive statistical values including arithmetic mean and standard deviation $(\mathrm{x} \pm \mathrm{SD})$ were calculated for all variables. Shapiro-Wilk normality test was used to determine whether the data showed normal distribution. The Paired t-Test was used to determine whether the changes over time in the variables recorded during the different measurement periods (pre-test, post-test) in the CTG and CONTG were different.

In addition, differences between CTG and CONTG for each measurement period were evaluated by the independent-samples t-test. Statistical procedures were performed in SPSS package software and $\alpha=0.05$ error level were applied to all statistical procedures 


\section{Result}

Table 4. Comparison of pre-test and post-test for conventional training group and core

\begin{tabular}{|c|c|c|c|c|c|c|}
\hline & Protocol & Test Order & Mean & SS & $\mathrm{T}$ & $\mathrm{P}$ \\
\hline \multirow{4}{*}{$\begin{array}{l}\text { Flamingo Balance Test } \\
\text { (Error hit) }\end{array}$} & \multirow[t]{2}{*}{ CTG } & Pre-Test & 14.463 & 4.202 & \multirow[t]{2}{*}{5.652} & \multirow[t]{2}{*}{$.000 *$} \\
\hline & & Final Test & 7.264 & 5.061 & & \\
\hline & \multirow[t]{2}{*}{ CONTG } & Pre-Test & 5.931 & 4.182 & \multirow[t]{2}{*}{.871} & \multirow[t]{2}{*}{.391} \\
\hline & & Final Test & 5.332 & 5.102 & & \\
\hline \multirow{4}{*}{$\begin{array}{l}\text { Core Stabilization Balanca } \\
\text { Test (sec.) }\end{array}$} & \multirow[t]{2}{*}{ CTG } & Pre-Test t & 80.401 & 26.421 & \multirow[t]{2}{*}{-6.562} & \multirow[t]{2}{*}{$.000 *$} \\
\hline & & Final Test & 132.661 & 37.903 & & \\
\hline & \multirow[t]{2}{*}{ CONTG } & Pre-Test & 95.603 & 48.792 & \multirow[t]{2}{*}{-.053} & \multirow[t]{2}{*}{.953} \\
\hline & & Final Test & 96.001 & 43.473 & & \\
\hline \multirow[t]{4}{*}{ Back Strength Testi (kg) } & \multirow[t]{2}{*}{ CTG } & Pre-Test & 52.001 & 10.431 & \multirow[t]{2}{*}{-.612} & \multirow[t]{2}{*}{.552} \\
\hline & & Final Test & 52.701 & 10.801 & & \\
\hline & \multirow[t]{2}{*}{ CONTG } & Pre-Test & 95.602 & 12.502 & \multirow[t]{2}{*}{-.443} & \multirow[t]{2}{*}{.661} \\
\hline & & Final Test & 90.112 & 11.951 & & \\
\hline \multirow[t]{4}{*}{ Leg Strength Test (kg) } & \multirow[t]{2}{*}{ CTG } & Pre-Test & 46.961 & 11.413 & -.322 & .752 \\
\hline & & Final Test & 48.083 & 18.611 & & \\
\hline & CONTG & Pre-Test & 52.001 & 15.151 & -1.431 & .173 \\
\hline & & Final Test & 53.602 & 15.952 & & \\
\hline Long Jump with Pause & CTG & Pre-Test & 149.401 & 15.041 & .353 & .722 \\
\hline Test $(\mathrm{cm})$ & & Final Test & 148.732 & 12.713 & & \\
\hline & CONTG & Pre-Test & 145.261 & 12.391 & -.152 & .873 \\
\hline & & Final Test & 145.463 & 13.261 & & \\
\hline Vertical Jump Test (cm) & CTG & Pre-Test & 26.662 & 5.811 & -1.673 & .112 \\
\hline & & Final Test & 28.801 & 6.381 & & \\
\hline & CONTG & Pre-Test & 35.932 & 6.461 & .442 & .663 \\
\hline & & Final Test & 35.603 & 5.573 & & \\
\hline Right-Hand Grip Test (kg.) & CTG & Pre-Test & 12.122 & 3.392 & -2.263 & $.044^{*}$ \\
\hline & & Final Test & 12.312 & 2.942 & & \\
\hline & CONTG & Pre-Test & 12.641 & 3.573 & .402 & .692 \\
\hline & & Final Test & 12.513 & 3.882 & & \\
\hline Left-Hand Grip Test (kg.) & CTG & Pre-Test & 11.924 & 2.951 & -2.673 & $.012 *$ \\
\hline & & Final Test & 12.592 & 3.291 & & \\
\hline & CONTG & Pre-Test & 11.352 & 3.101 & -1.291 & .214 \\
\hline & & Final Test & 11.763 & 3.792 & & \\
\hline 30 sn. Crunch Test & CTG & Pre-Test & 12.802 & 2.881 & -7.753 & $.000^{*}$ \\
\hline (Repetitions) & & Final Test & 18.533 & 3.522 & & \\
\hline & CONTG & Pre-Test & 14.662 & 5.991 & -1.731 & .103 \\
\hline & & Final Test & 17.132 & 6.581 & & \\
\hline 30 sn. Push-up Test & CTG & Pre-Test & 11.601 & 4.462 & -1.112 & .282 \\
\hline (Repetitions) & & Final Test & 13.402 & 6.042 & & \\
\hline & CONTG & Pre-Test & 11.803 & 4.373 & -3.821 & $.000 *$ \\
\hline & & Final Test & 16.462 & 3.312 & & \\
\hline $30 \mathrm{~m}$. Sprint Test (sec.) & CTG & Pre-Test & 5.531 & .351 & -2.353 & $.033^{*}$ \\
\hline & & Final Test & 5.562 & .362 & & \\
\hline & CONTG & Pre-Test & 5.281 & .413 & -1.872 & .082 \\
\hline & & Final Test & 5.372 & .461 & & \\
\hline
\end{tabular}

Note. $\mathrm{P}<0.05$.

In this study, as a result of pre-test and final test comparisons, a statistically significant difference was found in flamingo balance, core stabilization balance, right and left-hand grip, 30 -second abdominal crunch and pace test for CTG $(\mathrm{p}<0.05)$ while a statistically significant difference was found in 30 -second push-up test for CONTG $(\mathrm{p}<0.05)$. 
Table 5. Intergroup comparison in different measurement periods (pre-test - post-test)

\begin{tabular}{|c|c|c|c|c|c|c|}
\hline & Test Order & Protocol & Mean & SS & $\mathrm{T}$ & $P$ \\
\hline \multirow{4}{*}{$\begin{array}{l}\text { Flamingo Balance Test } \\
\text { (Error hit) }\end{array}$} & Pre-Test & CTG & 14.462 & 4.201 & 5.572 & $.000^{*}$ \\
\hline & & CONTG & 7.261 & 5.062 & & \\
\hline & Final Test & CTG & 5.932 & 4.181 & 1.041 & .301 \\
\hline & & CONTG & 5.331 & 5.103 & & \\
\hline \multirow{4}{*}{$\begin{array}{l}\text { Core Stabilization } \\
\text { Balanca Test (sec.) }\end{array}$} & Pre-Test & CTG & 80.402 & 26.422 & -1.063 & .292 \\
\hline & & CONTG & 132.661 & 37.903 & & \\
\hline & Final Test & CTG & 95.602 & 48.792 & 2.462 & 0.21 \\
\hline & & CONTG & 961 & 43.473 & & \\
\hline \multirow[t]{4}{*}{ Back Strength Testi (kg) } & Pre-Test & CTG & 52.002 & 10.432 & 1.443 & .152 \\
\hline & & CONTG & 52.701 & 10.801 & & \\
\hline & Final Test & CTG & 95.602 & 12.504 & 1.494 & .453 \\
\hline & & CONTG & 90.001 & 11.953 & & \\
\hline \multirow[t]{4}{*}{ Leg Strength Test (kg) } & Pre-Test & CTG & 46.962 & 11.412 & -1.022 & .312 \\
\hline & & CONTG & 48.081 & 18.613 & & \\
\hline & Final Test & CTG & 52.002 & 15.154 & -.872 & .381 \\
\hline & & CONTG & 53.601 & 15.953 & & \\
\hline \multirow{4}{*}{$\begin{array}{l}\text { Long Jump with Pause } \\
\text { Test }(\mathrm{cm})\end{array}$} & Pre-Test & CTG & 149.403 & 15.042 & .823 & .413 \\
\hline & & CONTG & 148.731 & 12.714 & & \\
\hline & Final Test & CTG & 145.263 & 12.393 & .692 & .492 \\
\hline & & CONTG & 145.262 & 13.262 & & \\
\hline \multirow[t]{4}{*}{ Vertical Jump Test (cm) } & Pre-Test & CTG & 26.661 & 5.814 & -4.123 & $.000 *$ \\
\hline & & CONTG & 28.803 & 6.382 & & \\
\hline & Final Test & CTG & 35.931 & 6.463 & -3.102 & $.043 *$ \\
\hline & & CONTG & 35.602 & 5.572 & & \\
\hline \multirow{4}{*}{$\begin{array}{l}\text { Right-Hand Grip Test } \\
\text { (kg.) }\end{array}$} & Pre-Test & CTG & 12.123 & 3.393 & -.403 & .682 \\
\hline & & CONTG & 12.312 & 2.942 & & \\
\hline & Final Test & CTG t & 12.641 & 3.571 & .632 & .533 \\
\hline & & CONTG & 12.513 & 3.881 & & \\
\hline \multirow[t]{4}{*}{ Left-Hand Grip Test (kg.) } & Pre-Test & CTG & 11.921 & 2.953 & .513 & .612 \\
\hline & & CONTG & 12.593 & 3.292 & & \\
\hline & Final Test & CTG & 12.641 & 3.571 & .632 & .521 \\
\hline & & CONTG & 11.763 & 3.792 & & \\
\hline \multirow{4}{*}{$\begin{array}{l}30 \text { sn. Crunch Test } \\
\text { (Repetitions) }\end{array}$} & Pre-Test & CTG & 12.802 & 2.881 & -1.083 & .281 \\
\hline & & CONTG & 18.533 & 3.522 & & \\
\hline & Final Test & CTG & 14.661 & 5.991 & .723 & .473 \\
\hline & & CONTG & 17.133 & 6.583 & & \\
\hline \multirow{4}{*}{$\begin{array}{l}30 \text { sn. Push-up Test } \\
\text { (Repetitions) }\end{array}$} & Pre-Test & CTG & 11.601 & 4.461 & -.112 & .902 \\
\hline & & CONTG & 13.403 & 6.042 & & \\
\hline & Final Test & CTG & 11.801 & 4.371 & -1.723 & .091 \\
\hline & & CONTG & 16.462 & 3.312 & & \\
\hline \multirow[t]{4}{*}{$30 \mathrm{~m}$. Sprint Test (sec.) } & Pre-Test & CTG & 5.533 & .351 & 1.732 & .093 \\
\hline & & CONTG & 5.562 & .362 & & \\
\hline & Final Test & CTG & 5.283 & .411 & -1.201 & .212 \\
\hline & & CONTG & 5.372 & .463 & & \\
\hline
\end{tabular}

Note. $\mathrm{P}<0.05$.

When the pre-test results of CTG and CONTG were compared, a statistically significant difference was found in flamingo balance and vertical jump tests $(\mathrm{p}<0.05)$. When the final tests were compared, a statistically significant difference was found in core stabilization and vertical jump tests $(\mathrm{p}<0.05)$.

\section{Discussion and Conclusion}

This study aimed to analyze the effect of a 6-week core training on certain biomotor abilities for footballers in the pubertal period. Many research on developing core strength for achieving sportive success was found in the literature. Findings obtained in this research was in line with the relevant literature.

Balaji and Murugavel (2013) have reported that the sprint performance essential for footballers developed positively with core training. Boyacı and Afyon (2017) found that 12-week core training developed footballers' $20 \mathrm{~m}$. sprint, vertical jump, and long jump with pause performances, and abdominal crunch and push-up values 
of footballers showed progress after core training. Furthermore, this can trigger a performance increase for $12-$ 14 year-old footballers as they are in puberty period. In the study carried out by Afyon and Boyac1 (2014) on sedentary groups and footballers, it was found that core training improves push-up and abdominal crunch performances, contributes to muscle durability considerably, and balance parameters can be improved with core training. Suna and Alp (2019) reported that the difference in push-up values in their study. Researchers emphasized that values found were higher may be due to the fact those participants apply the trainings more. In the study analyzing the effect of eight-week core training on certain physical and physiological parameters for footballers, Doğan et al. (2016) applied core training program in addition to the 8-week training for core training group while the control group was asked to continue conventional training only. When pre-test and final test values were compared for the control group, a significant improvement was found in body weight index, body weight, vertical jump, leg and back strength values. However, when the differences between the groups were evaluated, it was found that flexibility, leg and back strength, 20-meter-pace and VO2max parameters of the core training group showed progress further. Parkhouse et al. (2011) have reported that 6-week static core training for footballers improved their 20-meter sprint performance.

Boyacı and Tutar (2018) have reported that the Quad-Core training program procedure they applied on child athletes improved core muscle strength and durability. In the study where a core training program was applied, Carpes et al. (2008) found that core training improved the back and leg strength when performed regularly. In the study where the effect of core training applied regularly on male high school students was analyzed, Tokgöz (2017) have reported that the back and leg strength of the children performing core training regularly showed progress positively. Cosio-Lima et al. (2003) found that back strength showed progress as a result of 5-week-core training program they applied to the research group. Casio-Lima et al. (2003) applied core stability strength training and achieved a higher change and significant result in knee flexion and extension strengths when compared to the control group which performed no training. Reed et al. (2012) evaluated 24 different experimental studies in their compilation study discussing the effects of core stability training on athlete performance. The study revealed that there was a significant relationship between core stability and athlete performance. Sekendiz et al. (2010) found that core training applied with swiss-ball improved the back strength. Tamer et al. (2018) have reported that the athletes' aerobic power (MaxVO2) and 10-30 m. sprint abilities showed progress as a result of an 8-week exercise program. Kibler et al. (2006) have reported that core muscles provide stability to the abdomen, back, spine and hip. Furthermore, scientific studies have shown that core muscles played an effective role in generating the strength needed to perform the rotational movement between the hips and back. Schiffer et al. (2008) found that core training has a positive effect on vertical jump performance. Also, Sato and Mohka (2009) have reported that core exercises have a positive effect on balance performances. Baydemir and Alp (2018) found significant differences in balance tests in soccer players. Kean et al. (2006) found that core training enables abdominal muscle activation. İmai et al. (2014) have reported that core training developed the control and balance the ability of the body and played an effective role for muscles to gain strength. Prieske et al. (2015) have stated that a 9-week core training applied additionally in their study positively contributed to $10-20 \mathrm{~m}$. sprint performances.

Axel (2013) applied an 8-week core training to 19 surfers with an average age of was 15 years. It was found that the surfers developed their strength, balance, and agility abilities. In the study on baseball players, Lust et al. (2009) analyzed the difference between the core training group and the group that did not perform core training and revealed that the core training group made progress in the Sorensen and side bridge test. Samson (2005) applied core training to 13 tennis players (average age: 20) three days a week for 30 minutes and discussed the relationship between training and dynamic balance. As a result of the study, a significant difference was found in certain physical parameters. Weston et al. (2013) carried out an experimental study on 32 golf players (club players) to analyze core training. The experimental group carried out an 8-week training program consisting of basic level core exercises in addition to their routine training and the measurements were made for Backspine, Sidespine, pace, and core durability. As a result of the study, it has been reported that there was a significant difference in the measured abilities and the training program was successful.

Aiming to reveal the effects of core training program applied with body weight in addition to the annual training program of the footballers in puberty period, this study showed that the core training applied was an effective method for developing basic biomotor abilities. Football managers and athletic performance coaches working with youth teams in football clubs are advised to add core training exercises to their annual training program.

\section{References}

Afyon, Y. A. (2014). Effect of core training on 16-year-old soccer players. Educational Research and Reviews, $9(23), 1275-1279$. 
Akman, T., Kabadayı, M., Elioz, M., Cilhoroz, B., \& Akyol, P. (2013). Effect of jogging and core training after supramaximal exercise on recovery. Effect of jogging and core training after supramaximal exercise on recovery. Turkish Journal of Sport and Exercise, 15(1), 73-77.

Aktaş, S., Tatlici, A., \& Çakmakçi, O. (2019). Determination of Isokinetic Strength of Upper and Lower Body of Elite Male Boxers. Turkish Journal of Sport and Exercise, 21(2), 188-191. https://doi.org/10.15314/tsed.600645

Akyüz, M., Agar, M., Akyüz, Ö., \& Dogru, Y. (2016). Motivational Factors Affecting Athletes in Selecting the Sport Branches of Athletics, Ski and Tennis. Journal of Education and Training Studies, 4(12), 160-165. https://doi.org/10.11114/jets.v4i12.1961

Akyüz, M., Uzaldi, B. B., Akyüz, Ö., \& Doğru, Y. (2016). Comparison of Sprint Reaction and Visual Reaction Times of Athletes in Different Branches. Journal of Education and Training Studies, 5(1), 94-100. https://doi.org/10.11114/jets.v5i1.1987

Akyüz, Ö., Çoban, C., Dilber, A. O., Ergün, Z., Murat, T., Özkan, I., \& Akyüz, M. (2016). İşitme Engellilerde Statik Denge Düzeylerinin Belirlenmesi. Gaziantep Üniversitesi Spor Bilimleri Dergisi, 1(2), 110-116.

Axel, T. A. (2013). The effects of a core strength training program on field testing performance outcomes in junior elite surf athletes. California State University, Long Beach.

Baechle, T. R., \& Earle, R. W. (Eds.). (2008). Essentials of strength training and conditioning. Human kinetics.

Balaji, E., \& Murugavel, K. (2013). Motor fitnes parameters response to core strength training on Handbal Players. International Journal for Life Sciences and Educational Research, 1(2), 76-80.

Baydemir, B. \& Alp, M. (2018). The effects of specific trainings applied to 14 age male soccer players on their balance, sprint a nd technical skills. Journal of Education and Training Studies. Vol. 6, No. 11: 27-31. https://doi.org/10.11114/jets.v6i113415

Bergmark, A. (1989). Stability of the lumbar spine: a study in mechanical engineering. Acta Orthopaedica Scandinavica, 60(230), 1-54. https://doi.org/10.3109/17453678909154177

Biçer, Y., Savucu, Y., Kutlu, M., Kaldırımcı, M., \& Pala, R. (2004). Influence of Mentally Retarded Children on Movement Skills and Abilities. Surveys in Eastern Anatolia Region, 3(1), 173-179.

Boyac1, A., \& Afyon, Y. A. (2017). The Effect of the Core Training to Physical Performance in Children. Journal of Education and Practice, 8(33), 81-88.

Boyle, M. (2004). Functional training for sports. England: Human Kinetics Publishers.

Çakmakçı, E., Tatlıcı, A., Kahraman, S., Yılmaz, S., Ünsal, B., \& Özkaymakoğlu, C. (2019). Does once-a-week boxing training improve strength and reaction time? Uluslararası Spor Egzersiz ve Antrenman Bilimi Dergisi, 5(2), 88-92. https://doi.org/10.18826/useeabd.552086

Çakmakçi, E., Tatlici, A., \& Yirmibeş, B. (2018). Comparıson Of Some Performance Parameters of Physıcally Actıve Mentally Retarded and Inactive Mentally Retarded Individuals. European Journal of Physical Education and Sport Science, 4(12), 49-57.

Carpes, F. P., Reinehr, F. B., \& Mota, C. B. (2008). Effects of a program for trunk strength and stability on pain, low back and pelvis kinematics, and body balance: a pilot study. Journal of Bodywork and Movement Therapies, 12(1), 22-30. https://doi.org/10.1016/j.jbmt.2007.05.001

Clark, M. A. (2001). Core stabilization training in rehabilitation. Techniques in Musculoskeletal Rehabilitation. Prentice, New York, 259-278.

Cosio-Lima, L. M., Reynolds, K. L., Winter, C., Paolone, V., \& Jones, M. T. (2003). Effects of physioball and conventional floor exercises on early phase adaptations in back and abdominal core stability and balance in women. The Journal of Strength \& Conditioning Research, 17(4), 721-725. https://doi.org/10.1519/00124278-200311000-00016

Dello, I. A., Padulo, J., \& Ayalon, M. (2016). Core stability training on lower limb balance strength. Journal of Sports Sciences, 34(7), 671-678. https://doi.org/10.1080/02640414.2015.1068437

Doğan, G., Mendeş, B., Akcan, F., \& Tepe, A. (2016). The Effects of Eight-week Core Training on Some Physical and Physiological Parameters of Football Players. Niğde University Journal of Physical Education And Sport Sciences, 10(1), 1-12. 
Doğru, Y., Akyüz, M., Akyüz, Ö., Murat, T. A. Ş., Çoban, C., \& Dilber, A. O. (2018). The Effect of Eight-Week Resistance Exercise Program on Static Balance in Sedentary Men Aged 20-40 Years. International Journal of Sport Culture and Science, 6(2), 245-253. https://doi.org/10.14486/IntJSCS756

Eniseler, N. (1994). Physiological factors affecting football. Journal of Football Science and Technology, 1(1), $10-12$.

Faries, M. D., \& Greenwood, M. (2007). Core training: stabilizing the confusion. Strength and Conditioning Journal, 29(2), 10. https://doi.org/10.1519/00126548-200704000-00001

Fig, G. (2005). Strength training for swimmers: Training the core. Strength \& Conditioning Journal, 27(2), 4042. https://doi.org/10.1519/00126548-200504000-00008

Günay, M., Tamer, K., \& Cicioğlu, İ. (2010). Sport physiology and performance measurement. Ankara: Gazi Bookstore Publisher.

Handzel, T. M. (2003). Core training for improved performance. NSCA's Performance Training Journal, 2(6), $26-30$.

Hazar, F., \& Taşmektepligil, Y. (2008). The effects of balance and flexibility on agility in prepuberte period. Spormetre Journal of Physical Education and Sports Science, 6, 9-12. https://doi.org/10.1501/Sporm_0000000130

Iacono, A. D., Martone, D., Alfieri, A., Ayalon, M., \& Buono, P. (2014). Core Stability Training Program (CSTP) effects on static and dynamic balance abilities. Gazzetta Medica Italiana Archivio per le Scienze Mediche, 173(4), 197-206.

Imai, A., Kaneoka, K., Okubo, Y., \& Shiraki, H. (2014). Effects of two types of trunk exercises on balance and athletic performance in youth soccer players. International Journal of Sports Physical Therapy, 9(1), 47. PMC3924608

Kean, C. O., Behm, D. G., \& Young, W. B. (2006). Fixed foot balance training increases rectus femoris activation during landing and jump height in recreationally active women. Journal of Sports Science \& Medicine, 5(1), 138.

Kibler, W. B., Press, J., \& Sciascia, A. (2006). The role of core stability in athletic function. Sports Medicine, 36(3), 189-198. https://doi.org/10.2165/00007256-200636030-00001

Köklü, Y., Özkan, A., Alemdaroğlu, U., \& Ersöz, G. (2009). The comparison of some physical fitness and somatotype characteristics of young soccer players according to their playing positions. Ankara University School of Physical Education and Sports Spormetre Physical Education and Sports Science Journal, 7(2), 61-68.

Lust, K. R., Sandrey, M. A., Bulger, S. M., \& Wilder, N. (2009). The effects of 6-week training programs on throwing accuracy, proprioception, and core endurance in baseball. Journal of Sport Rehabilitation, 18(3), 407-426. https://doi.org/10.1123/jsr.18.3.407

Mackenzie, B. (2005). Performance evaluation tests. Electric World PLC, 24(25), 57-158.

McGill, S. (2010). Core training: Evidence translating to better performance and injury prevention. Strength \& Conditioning Journal, 32(3), 33-46. https://doi.org/10.1519/SSC.0b013e3181df4521

McGill, S. M., Grenier, S., Kavcic, N., \& Cholewicki, J. (2003). Coordination of muscle activity to assure stability of the lumbar spine. Journal of Electromyography and Kinesiology, 13(4), 353-359. https://doi.org/10.1016/S1050-6411(03)00043-9

Muratl, S. (2007). Children and sports. Ankara: Nobel Publisher.

Parkhouse, K. L., \& Ball, N. (2011). Influence of dynamic versus static core exercises on performance in field based fitness tests. Journal of Bodywork and Movement Therapies, 15(4), 517-524. https://doi.org/10.1016/j.jbmt.2010.12.001

Prieske, O., Muehlbauer, T., Borde, R., Gube, M., Bruhn, S., Behm, D. G., \& Granacher, U. (2016). Neuromuscular and athletic performance following core strength training in elite youth soccer: Role of instability. Scandinavian Journal of Medicine \& Science in Sports, 26(1), 48-56. https://doi.org/10.1111/sms.12403

Reed, C. A., Ford, K. R., Myer, G. D., \& Hewett, T. E. (2012). The effects of isolated and integrated 'core stability'training on athletic performance measures. Sports Medicine, 42(8), 697-706. 
https://doi.org/10.1007/BF03262289

Riewald, S. T. (2003). Training the "other core". Performance Training Journal, 2(3), 5-6.

Saeterbakken, A. H., Van den Tillaar, R., \& Seiler, S. (2011). Effect of core stability training on throwing velocity in female handball players. The Journal of Strength \& Conditioning Research, 25(3), 712-718. https://doi.org/10.1519/JSC.0b013e3181cc227e

Samson, K. M. (2005). The effects of a five-week core stabilization-training program on dynamic balance in tennis athletes. West Virginia University.

Sato, K., \& Mokha, M. (2009). Does core strength training influence running kinetics, lower-extremity stability, and 5000-M performance in runners? The Journal of Strength \& Conditioning Research, 23(1), 133-140. https://doi.org/10.1519/JSC.0b013e31818eb0c5

Schiffer, T., Schulte, S., \& Sperlich, B. (2008). Aerobic dance: health ve fitness effects in middle aged premenopausal women. Journal of Exercise Physiology Online, 11(4), 25-33.

Sekendi, B., Cug, M., \& Korkusuz, F. (2010). Effects of swiss-ball core strength training on strength, endurance, flexibility and balance in sedentary women. The Journal of Strength \& Conditioning Research, 24(11), 3032-3040. https://doi.org/10.1519/JSC.0b013e3181d82e70

Sevim, Y. (2006). Training information. Ankara: Nobel Publishing House.

Stanton, R., Reaburn, P. R., \& Humphries, B. (2004). The effect of short-term Swiss ball training on core stability and running economy. The Journal of Strength \& Conditioning Research, 18(3), 522-528. https://doi.org/10.1519/00124278-200408000-00023

Sun, X., Gao, Q., Dou, H., \& Tang, S. (2016). Which is better in the rehabilitation of stroke patients, core stability exercises or conventional exercises? Journal of Physical Therapy Science, 28(4), 1131-1133. https://doi.org/10.1589/jpts.28.1131

Suna, G., Alp M. (2019). Comparison of strength, heart rate, oxygen saturation and technical test values of $12-$ 14 year male tennis players in competition period. Journal of Education and Learning; Vol. 8, No. 6: 187-194. https://doi.org/10.5539/jel.v8n6p187

Tatlıcı, A., Çakmakçı, E., Yılmaz, S., \& Arslan, F. (2018) Comparison of Visual Reaction Values of Elite Deaf Wrestlers and Elite Normally Hearing Wrestlers. Turkish Journal of Sport and Exercise, 20(2), 63-66. https://doi.org/10.15314/tsed.440813

Tatlici, A., \& Cakmakci, O. (2019). The effects of acute dietary nitrate supplementation on anaerobic power of elite boxers. Medicina Dello Sport, 72(2), 225-233.

Tatlici, A., Sercan, Y., \& Samet, A. (2018). Türkiye'de işitme engelliler ve spor. Türkiye birliği yayınları, 589598.

Tokgöz G. (2017). The Effect of Specially Designed Core Exercises on Upper Extremity Posture Structures of Male High School Students. Master Thesis, Firat University, Turkey.

Ünlü, G., \& Tatlıcı, A. (2018). Elit Güreşçilerde Proprioseptif Nöromuskuler Fasilitasyon (Pnf) Uygulamalarının Dinamik Denge Performansına Akut Etkileri. Sportif Bakış: Spor ve Eğitim Bilimleri Dergisi, 57-63.

Weston, M., Coleman, N. J., \& Spears, I.R. (2013). The effect of 1solated core training on selected measures of golf swing performance. Medicine Science Sports Exercise, 45(12), 2292-2297. https://doi.org/10.1249/MSS.0b013e31829bc7af

\section{Copyrights}

Copyright for this article is retained by the author, with first publication rights granted to the journal.

This is an open-access article distributed under the terms and conditions of the Creative Commons Attribution license (http://creativecommons.org/licenses/by/4.0/). 